\title{
The Communalization and Disintegration of Urdu in Anita Desai's In Custody
}

\section{Introduction}

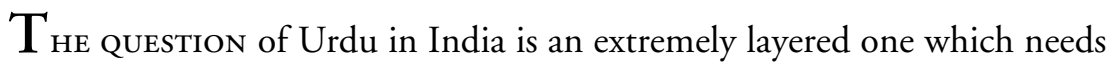
to be examined historically, politically and ideologically in order to grasp the various forces which have shaped its current perception as a sectarian language adopted by Indian Muslims, marking their separation from the national collectivity. In this article I wish to explore these themes through the lens of literature, specifically an Indian English novel about Urdu entitled In Custody by Anita Desai. Writing in the early I990s, Aijaz Ahmad was of the opinion that the teaching of English literature has created a body of English-speaking Indians who represent "the only" overarching national community with a common language, able to imagine themselves across the disparate nation as a "national literary intelligentsia" with "a shared body of knowledge, shared presumptions and a shared knowledge of mutual exchange" (1992, 278). ${ }^{2}$ Arguably both Desai and Ahmad belong to this "intelligentsia" through the postcolonial secular English connection, but equally they are implicated in the discursive structures of cultural hegemony in civil society (Viswanathan I989, I-22; Rajan 1992, 7-28). However, it is not my intention to re-inscribe an authentic myth of origin about Indianness through linguistic associations,

${ }^{1}$ An earlier version of this essay was first presented as a paper at the Minorities, Education and Language in $2 \mathrm{I}^{\text {st }}$ Century Indian Democracy-The Case of Urdu with Special Reference to Dr. Zakir Husain, Late President of India Conference held in Delhi, February 2002.

${ }^{2}$ See also chapter 7 "'Indian Literature': Notes Toward the Definition of a Category," in the same work, 243-86. 
but to critically assess the value of Anita Desai's intervention in a communally charged Hindi-Urdu debate.

The key questions I raise in this essay are about the kind of cultural memory Desai is constructing in her text, and how this depiction can be read in relation to the actual machinations of Indian politics with regard to the language question. As a successful author, writing for an international publishing market, she is invested with a certain power to imaginatively represent an "authentic" India. While she is not a writer who bombards us with an epic style narration, purporting to offer "the great Indian novel," her exploration of individual identities and selfformations work in a subtle and problematic way, creating instead miniatures, and guiding the reader's responses through a combination of omniscience, internal focalization, indirect speech and symbolic tropes.

In Custody, short-listed for the Booker Prize in 1984, can retrospectively be read as a literary narration of the communalization and disintegration of Urdu in post-Partition India. The year in which it was published was coincidentally the same year that saw the death of an Urdu literary legend, the master lyricist Faiz Ahmad Faiz who stirred the hearts of millions with his haunting melodies and sustained hope for many with his romantic vision of a return to a beloved homeland. Symbolizing optimism, his poetry revived disheartened nationalists with its belief in a destination which had as yet not been realized, a desire that marked even his most pessimistic poem "Ṣubh-e Āzādī: August 1947" ("Freedom's Dawn") with its important ideological rejection of the "pock-marked dawn" of freedom from colonial rule:

The time for the liberation of heart and mind

Has not come as yet

Continue your arduous journey

This is not your destination

(In Hasan 1988, 36)

It is interesting that Faiz, stylistically wedded to the traditional form of the ghazal, was concerned with forging themes of modernity in his poetic message, constructing a new direction for his Urdu listeners and readers, while Desai, working with a modernist narrative, takes it back toward a sensibility rooted in tradition and premodern aristocracy. Her 
idea of Urdu is that it is trapped in an aristocratic lineage, a theme which she also touches on in her earlier novel Clear Light of Day (1980). ${ }^{3}$ Desai's perception of Urdu as an artifact of Old India and its communal heritage are key features of her story. One of the narrative devices she uses is that of cultural memory and this, in connection with the theme of Urdu, is inevitably tied to the memory of separation and Partition. Here it is important to make the distinction that whereas Faiz is still looking for national liberation in "Șubḥ-e Âzādī," Desai is analyzing Urdu as the cultural object of a lived experience in post-Partition India. Later in his career, Faiz was commissioned by Zulfiqar Ali Bhutto's government in post-Partition Pakistan to conduct an "official" search for Pakistani culture and nationalism. His findings and ruminations were later collected and published in a volume entitled, Pakistānī Kalčar aur Qaumī Tashakhkhus kĩ Talāsh (Pakistani Culture and the Search for National Character) (1988). In that volume, it is evident that Faiz was driven by an Arnoldian sensibility toward culture, looking to preserve "the best that has been thought and said" in his search for a representative model of a collective Pakistani national consciousness (Eagleton 2000, 32). Desai's fiction, on the other hand, demystifies the idea of a national collectivity and looks toward the arts and the way of life of individuals as distinctive cultural representations. Her constructions of cultural memory are marked by nostalgia for the past, and a kind of closeness to the Romantic tradition with its "idealizing of the "folk," of vital subcultures buried deep within its own society" (ibid., 25).

Desai's narration of Urdu's tragedy is mediated through the eyes of an urban dweller in New Delhi struck by the lyrical romance of Old Delhi Urdu poetry, a remnant of a premodern cultural tradition that rememorizes the old city. In an interview with Magda Costa, Anita Desai responded to the suggestion that In Custody is a representation of the decay of Urdu literature as follows:

I was trying to portray the world of Urdu poets. Living in Delhi I was always surrounded by the sound of Urdu poetry, which is mostly recited. Nobody reads it, but one goes to recitations. It was very much the voice of North India. But although there is such a reverence for Urdu poetry, the

${ }^{3}$ See Part II which details Raja's attraction to Urdu poetry, his heroic character and his admiration for the neighbor and landlord, Hyder Ali, who encourages his interest in Urdu. 
fact that most Muslims left India to go to Pakistan meant that most schools and universities of Urdu were closed. So that it's a language I don't think is going to survive in India.... There are many Muslims and they do write in Urdu; but it has a kind of very artificial existence. People are not going to study Urdu in school and college anymore, so who are going to be their readers? Where is the audience?

(Costa 200I)

Aijaz Ahmad, tracing the history of Urdu language and literature from 1947 to 1965 , describes three aspects in the breakup and redistribution of the Urdu-writing community that changed the perception of Urdu after Partition. First was the migration and resettlement of religious communities across the newly-drawn borders; second was the increased communalization of Urdu as a Muslim language, its implementation as a national language in Pakistan and its decreasing status as a language of "minority right" and "Muslim interest" in India; and finally the Indian government's abandonment of Hindustani in favor of Hindi as the official language. In Ahmad's estimation the loss of Hindustani as a recognized lingua franca was a major event because it had served as a "living link between Urdu and Hindi which now became more and more distant from each other, especially in their written forms" (Ahmad 1996, 20I-2). In postcolonial India-specifically Uttar Pradesh where the mothertongue Urdu-speaker has been marginalized through a lack of representation in the linguistic federation of states- Urdu is indeed perceived as an endangered language by the minority who are literate in it.

For Ahmad, the political nation and the cultural community are the two ultimate "framing realities" that dominate post-Partition Urdu literary production in India and Pakistan. With the absence of a middleground Hindustani, the communal perception of Urdu as a Muslim language has become stronger. This religious separatism saturates the verse of a contemporary Urdu poet Rashīd Banārsī from Varanasi:

We understood a lot about the prejudices of this age

Today languages too are Brahmins and Shaikhs? We don't understand

If Urdu too is under blame for being an outsider

Then whose homeland is India? We don't understand.

(Quoted in Lee 2000, 338) 
There are interesting similarities between Desai, Ahmad and Rashìd Banārsī, all speaking of Urdu but in varying tones and differing forms. Desai's personal pessimistic view of Urdu's survival in India is tied to the fact of mass Muslim migration, Ahmad sees migration as a contributory factor to the break up of the Urdu-writing community, and Banārsi articulates the frustration that comes from Urdu's marginalized status and its perception as a migrant's tongue which makes him an outsider in his own homeland. The Urdu that was the "voice of North India" as Desai remembers it and its survival are indeed major concerns for Urdu traditionalists, and while the concerns are valid they reinforce a specific idea of Urdu and squeeze out its identity as a lingua franca. The limitation felt by poets such as Banārsī, who cannot escape the reflected cultural memory of Urdu, is recognized and reimagined in a novel such as In Custody. If a common historical moment is to be mentioned which changes the idea of Urdu in India then Partition is one such moment.

Sunil Khilnani in his insightful study, The Idea of India, has argued that Partition is a tangible memory on the Subcontinent

around which the inevitable disappointments of modern politics can gather.... Partition is the unspeakable sadness at the heart of the idea of India: a memento mori that what made India possible also profoundly diminished the integral value of the idea.

(I998, 200-O2)

For Khilnani the idea of India is ultimately a political one because in his view the history of India since 1947 is marked by a continuing faith in democratic procedures and is expressed through party politics; Indians have in the past been inspired by the charisma of the Congress Party, and more recently by regional, caste-based and communal political groupings. In this respect the evolving modern nation is still disrupted by hierarchical stratifications and-in the sometimes fraught relationship between Hindu and Muslim - the memories of its ruptured birth.

In Desai's book, when the protagonist Deven, a lecturer in Hindi, applies in person for one week's teaching leave in order to conduct an interview with the legendary Urdu poet Nur Shahjahanabadi, his head of department, Trivedi, meets the request with a virulent, short-tempered and communally charged reaction:

"I'll get you transferred to your beloved Urdu department. I won't have Muslim toadies in my department, you'll ruin my boys with your 
Muslim ideas, your Urdu language. I'll complain to the Principal, I'll warn the RSS [Rashtriya Swayamsevak Sangh] you are a traitor." (1985, I45)

Trivedi's reactionary stance encapsulates the culture of fear and paranoia that surround Hindi and Urdu speakers in a national climate where language is ironically both the carrier of religious identity and the mark of national loyalty. Trivedi's utterance, long before the destruction of the Babri Mosque in Ayodhya, has an ominous ring to it. With its evocation of the RSS, it can retrospectively be seen to anticipate the current Indian political climate, where his voice returns to haunt us in the Bombay riots, the violent eruptions in Gujarat, and the continuing Kashmir crisis.

\section{The Hindi-Urdu Divide}

The knotty issue of national language has been a topic of much scholarly deliberation in historiographical and sociological studies of the Indian nation. Several researchers have drawn our attention to the contentious fates of Hindustani, Urdu, and Hindi in nineteenth- and twentieth-century India. ${ }^{4}$ Such linguistic differences can be read as marking an important distinction from what Benedict Anderson has theorized as an integrated "Imagined Community" coming together through a common language via the rise of a homogenizing print capitalism (see Anderson I99I; Bhabha 1990). These studies have revealed a multilingual nation which cannot comfortably assimilate its diverse linguistic groups.

Urdu came to prominence in the middle-to-late eighteenth century at the same time as the ousting of Persian from the courts by the British and its replacement with the official language of government, English. Generally, in eastern and northern India, Bengali and Urdu remained in use in the lower levels of administration and judiciary, while in the northern state of Panjab, the British imposed English and Urdu "as the languages of government" (Bose and Jalal I998, 84-5). On an informal basis they relied on Hindustani/Urdu as a lingua franca in North India, while official recognition was accorded to the vernaculars on 4 September I837.

\footnotetext{
${ }^{4}$ This is reflected in the monographs of Shackle and Snell (1990), Rai (199I), Brass (1974), and King (1994).

${ }^{5}$ Urdu was recognized in Bihar, the United Provinces, Avadh and the Panjab while in the south it was patronized by the Nizams of Hyderabad.
} 
The Muslim reformer and early modernizer Sayyid Ahmad Khan was deeply influential in instigating linguistic reform and advocating cultural change for his community, however, his interventions for the cause of Urdu with the colonial government suffered setbacks in Bihar in I88I and in the United Provinces in 1900 under pressure from a rising middle-class Hindu lobby (Shackle and Snell I990, 8). According to Francis Robinson, the proposed replacement of Persian script by Devanagari led by a Hindu deputation in 1900 , and the British government's favorable response to it, marked a key moment in the increasing sense of separatism amongst Indian Muslims (1993, 133-74).

The historical perspective of Urdu's decline has been directly linked to Hindi's rise by Jyotirindra Das Gupta who charts the national movement alongside language associations in pre-Partition India (1970). He asserts that after 1882 the Hindi movements pressed for the teaching of Hindi universally in all primary and secondary schools in North India. It was in the northwestern provinces that the Hindi movement displayed a virulent stance toward Urdu.

The constant refrain of the public petitions was that Urdu was an alien language. A petition signed by 500 Hindi graduates and undergraduates declared Urdu to be 'an alien and upstart language' while another petition described Urdu as a 'hybrid production ... forced upon us by our former rulers.' (ibid., I03)

In Gupta's view, "a large part of the language conflict in Uttar Pradesh is influenced by the memories of past conflict transmitted to the Hindu and Muslim communities by the cultural and political leaders (ibid., I50)." For Gupta these conflictual linguistic associations can be historically

${ }^{6} \mathrm{While}$ the Hindi petitions gathered strength, there was only one petition, signed by a small number of people, submitted in favor of Urdu in the northwestern provinces. As this shows, language petitions in the nineteenth century were becoming communally charged and reflected the divisive forces of language and religion on the communities. The culture of language petitions survived in Independent India and the late Dr. Zakir Husain's act of collecting 2.25 million signatures from the Urdu-speaking people in Uttar Pradesh in 1952 supporting a petition asking the President to save Urdu under Article 347 of the Constitution proves a case in point. For a critical comment on politicians taking on the Urdu cause in Uttar Pradesh, see Latifi 1999, 44-6. 
linked to the shortsightedness of small élites whose community consciousness dictated their group loyalty in the transitional period from a traditional multilingual society to a modern nation. Thus in the early nationalist phase in India "leaders rarely drew a distinction between the categories of common language, national language and official language" (ibid., 36).

For David Lelyveld too, sociological perspectives are paramount in examining the organic history of languages such as Hindi and Urdu, rather than an abstract theorizing which focuses on, "who gets to speak, who is allowed to listen, which topics and settings are appropriate to which linguistic codes" (1993, 192). He suggests that in attempting to understand this linguistic code we may come closer toward grasping the unique formula which delicately balances the formation of self-conscious identity against the facts of power, competition and exploitation. To put his theory to the test, Lelyveld examines Gandhi's role in the nurture of an Indian national consciousness through a unified Indian language which would both reflect the self-identity of Indians and bridge the linguistic diversity of its many regions. He argues:

It would be debatable in 1916 to say that Hindi was Hindu and Urdu was Muslim, but there were certainly grounds and occasion for relating language and religion in this way. It was one of the central projects of Gandhi's life, and a tenet of the Indian National Congress after 1920, that the national language must overarch this distinction, that instead of being Hindi or Urdu, it should be Hindustani.

(ibid.)

Historically, the Indian National Congress gave official recognition to Hindustani in its 1934 constitution. Hindustani, suggested by Gandhi as a neutral solution to the thorny Hindi-Urdu controversy, would reflect a unified national consciousness free from religious affiliations. But the stumbling block around which the neutral solution fell apart was that of the script. In Sunil Khilnani's view, after independence: "Nehru's initial hope had been for India's regional states to continue as the mixed, multilingual administrative units established by the Raj" (1998, I75). Nehru's government resisted the pressures from the Hindi lobbyists for a centralizing national language and reached a compromise with the post-Partition Indian Constitution (1950) by recommending a fifteen-year usage of English for official purposes and the use of Hindi in the Devanagari script as the "official" language of the Union, while also extending recognition 
to other regional languages. But eventually this pluralism had to be altered to accommodate the demand for decentralization and the formation of linguistic states. The Official Languages Amendment Act of 1963 gave Hindi the hegemonic status of "official language" and English the secondary role of "associate or additional official language." The Official Languages Amendment Bill adopted in 1967 included the acceptance of a historic Three Language Formula which would be implemented in secondary education for language teaching. This formula recommends: "(a) the regional language and mother tongue when the latter is different from the regional language; (b) Hindi or, in Hindi-speaking areas, another Indian language; and (c) English or any other modern European language" (Gupta 1970, 243).

With regards to the situation of Urdu in contemporary India, the language controversies of the past have had a detrimental effect on the status of Urdu wherever religious identity has come to inform the ideologically separatist correlation of Muslim $=\mathrm{Urdu}=$ Pakistan and Hindu= Hindi=India. ${ }^{8}$ According to Athar Farouqui, the situation of the Urdu mother-tongue speaker has deteriorated in Uttar Pradesh to such an extent that "there is not even a single primary or junior high school of Urdu medium. The only two Urdu medium schools are run by and affiliated to Aligarh Muslim University" (1994, 782). For Farouqui, the Three Language Formula in Uttar Pradesh has thus far failed to serve the needs

${ }^{7}$ There were angry reactions to Hindi's elevation and violence-led rejection of this move in the southern states of Andhra Pradesh and Tamil Nadu. In 1968 there was an Official Languages Amendment Act which strengthened the position of English as the acceptable sister alternative to Hindi "without any certain deadline.”-(King 1994, 4-7).

${ }^{8}$ The Urdu-as-Muslim issue has been particularly volatile in the state of Uttar Pradesh (UP) where the recent bone of contention has been the alleged statistical miscounting of mother-tongue Urdu-speakers. UP, once the heartland of Urdu's urban élite, is now unable to meet the needs of its mother-tongue speakers. Political intervention on a regional scale was officially led by Dr. Zakir Husain and a 7-member Urdu-speakers deputation to the UP education minister (Sampurnanand) in 1952, registering the marginalization of Urdu in the state. In I958 the grievances were made known at a national level to the President of India and a request was made under Article 347 of the Constitution for the recognition of Urdu in UP, Bihar, Panjab and Delhi. In 1958 Sampurnanand, then chief minister of UP, said that Urdu could not be recognized as a regional language in UP in the Legislative Assembly. 
of mother-tongue speakers of minority languages. He passionately dismisses the formula as a whitewash as far as the Urdu language is concerned, and is outraged at the whimsical interpretation of the North Indian chief ministers in their implementation of it by recognizing Hindi as the regional language, Sanskrit as the modern language and English as the foreign language. To him this signifies a sinister political manipulation of the Urdu minority in North India, particularly at the time of census collection which, he argues, took for granted that everyone's mothertongue in the area was Hindi (ibid., 783). In Zoya Hasan's estimation, the Hindi-Urdu controversy in UP has an explicit agenda of "political dominance and equally significant subtexts on the cultural identity of the state and alternative conceptions of political community" (1998, I87). Hasan places the blame squarely on government policy which has treated Urdu as a minority Muslim affair breaching the stance on linguistic pluralism and the separation of language and religion. The conflation of language and religion in the Sanskritized official Hindi expansion program has also created further alienation and division amongst the already communalized linguistic groups (ibid., I87-8; on this subject also see Jaffrelot 1998).

\section{The Decay of Urdu in Custody}

In Custody tells the story of the decline and decay of Urdu in modern India. Deven, the antihero of the novel, is a Hindi lecturer devoted to the classical tradition of Urdu poetry, a devotion which stems from his childhood associations with the language as a mother-tongue speaker. Born in Lucknow, educated in Delhi, he is a poor widower's son who has found employment as a university lecturer in Lala Ram Lal College in Mirpore. While his career choice is not particularly lucrative as a language specialist, it has been directed by a practical consideration of the market economy that favors Hindi, the language of communication in North India. Urdu fuels his imagination and Hindi sustains his corporeal needs: "I am-only a teacher ... and must teach to support my family. But poetry-Urdu - ... I need to serve them to show my appreciation” (1985, 43). Deven feels trapped in the confines of his chosen home, so when the opportunity of returning to the capital presents itself through the intervention of his childhood friend Murad, he takes an uncharacteristically risky step by agreeing to Murad's suggestion. In taking this decision he is temporarily freed from the constrictions of his existence in the small town of Mirpore, which had come to resemble the metaphorically "impassable 
desert that lay between him and the capital with its lost treasures of friendships, entertainment, attractions and opportunities" (ibid., 24).

The northern plain of Mirpore situated "more than a thousand miles from the coast" had been shaped by the presence of a Muslim aristocracy, in this case a long-forgotten nawab who had fled Delhi to escape the aftermath of the 1857 Mutiny and had subsequently built a mosque in Mirpore as a memorial of thanks to his Supreme Benefactor for preserving his life. The narrator tells us that the history of the mosque has been swept away in the dust which saturates the Mirpore atmosphere and all that remains of the "marble and pink sandstone" is a decaying filthridden stone structure overtaken by the debris of modernity. But the narrator reiterates its ongoing use as a mosque. Continuing to map the cultural traditions of Mirpore the narrator tells us: "The temples were more numerous but had no history at all. There was literally not a man in Mirpore who could have told one when they were built or by whom" (ibid., 20).

Here it can be argued that Desai's reconstruction of the geography of Mirpore is interesting and problematic because it links the Muslim presence in Mirpore to a premodern urban aristocracy and contrasts it with the timelessness of an indigenous Hindu tradition which is embedded in an infinite antiquity: "the same kind of antiquity that the shacks of the poor had, and the stalls of the traders - they were often wrecked, rebuilt and replaced, but their essential form remained the same" (p. 20). While it is in no way my intention to suggest that Anita Desai is articulating a communalist viewpoint, there is a particular historical and ideological freight surrounding the usage of Hinduism as timeless and Islam as latecomer which the narrative inevitably duplicates. The miniature portrait of the town grafted onto the larger narrative of Urdu replicates what, to borrow a phrase from Edward Said, might be seen as a "problematic structure of attitude and reference" regarding a whole cultural tradition. ' The

${ }^{9}$ Edward Said borrows and modifies Raymond Williams' phrase "structure of feeling," as "structures of attitude and reference," to describe "the way in which structures of location and geographical reference appear in the cultural languages of literature, history, or ethnography, sometimes allusively and sometimes carefully plotted, across several individual works that are not otherwise connected to one another or to an official ideology of 'empire"' ( I993, 6I). I consider such structures to be inherent in all hegemonic discourses which address an 
narrator tells us that the Mirpore communities were mutually observant of the stratified "Muslim" and "Hindu" areas. While this separation was habitual and uneventful for the most part, police had to be brought in from time to time when the ritual mourning of Muharram coincided with the festival of Holi. Despite the police, the communities

clashed ... from time to time, knives flashed, batons flailed and blood ran. For a while tension was high, the newspapers-both in Hindi and Urdu -were filled with guarded reports and fulsome editorials on India's secularity while overnight news-sheets appeared with less guarded reports laced with threats and accusations. (ibid., 2I)

Here, the reference to the Hindi and Urdu newspapers is highly charged and can be seen to be indicative of the manipulation of ethnic differences in the regional print media. This print culture has the power to stoke the fires of dissension in a tense situation and intensify a separatist stance through divisive linguistic narratives.

The novel begins with an unscheduled meeting between two childhood friends with contrasting personalities and backgrounds, namely Deven and Murad, his Muslim friend, "the spoilt rich boy with money in his pocket for cinema shows and cigarettes" (ibid., II). The story symbolically unfolds at the beginning of spring in the month of March signifying the theme of birth and hope. The encounter between the two friends takes place on the grounds of Deven's college. Murad has traveled from Delhi to Mirpore, metaphorically tearing across the plain like the changeable March wind "whirling dust and dry leaves around violently" (ibid., Io), to involve Deven in his latest project and sow the seeds of Deven's fateful journey from Mirpore to Delhi. This initial paired characterization of the two friends underlines Murad as active and Deven as passive. However, Murad's active nature is supplanted by the darkness of his actions. He comes to embody the exploitative city with its disregard for sentiment or nostalgia. In contrast, Deven's residual passivity makes him the unfortunate vessel of many betrayals, ultimately unable to cope with the pressures of modern living.

Deven is coerced by Murad to interview the renowned Delhi poet Nur Shahjahanabadi for a "special issue" of his Urdu journal Awaz.

"other" from a position of power, as is the case with Urdu in India and the problematic place of Islam in Indian history. 
Murad's outlook on Urdu is marked by a sense of the "glorious" past and an intention to recover the lost high cultural tradition that flourished in the premodern urban literary landscape in order to rescue it from its present relegation to the nameless margins of the city. He says he wishes to

"keep alive the glorious tradition of Urdu literature. If we do not do it, at whatever cost, how will it survive in this era of-that vegetarian monster, Hindi?" ... "That language of peasants," Murad sneered, picking his teeth with a matchstick. "The language that is raised on radishes and potatoes ... it flourishes, while Urdu-language of the court in days of royalty —now languishes in the back lanes and gutters of the city." (ibid., I5)

Murad feels he is on higher moral ground because, unlike Deven, he has not surrendered to Hindi. His job as an Urdu editor displays his commitment and lifelong struggle in the cause of a golden tradition despite the constant worries of diminishing subscriptions, low readership, and escalating production costs. He accuses Deven of betraying his mother-tongue by selling out to the professional service of its archrival Hindi. This accusation is to haunt Deven throughout the book every time he enters the Urdu arena.

Murad is facially disfigured by pockmarks, rather like his beloved Urdu which no longer has the patronage of emperors and nawabs, and while his scarred face marks him as a metaphor for Urdu, it can also be read as a symbol of an Urdu-speaker tainted by his contempt for Hindi. However his prejudicial attitude toward Hindi does not seem to extend to a communal rejection of Hindus since he confers custody of Urdu on Deven. He tells Deven:

"Nur will be the star of the issue. The light that blazes in the center and sends its rays to all corners of the world where his verse is known-in Iran, Iraq, Malaysia, Russia, Sweden-do you know, we have sent his name to the Nobel Prize Committee for its award for literature once again?” ...

... "I want a full feature on Nur-Nur in his old age, the dying Nur before he is gone, like a comet into the dark. I want you to do that feature." (ibid., 17)

Here Desai's reference to a well-known, socially aware poet may be seen as an indirect nod in the direction of Faiz, the revolutionary Progressive poet who was awarded the Lenin Peace Prize in 1962. Desai's narrative has a lyrical quality, with its use of symbolic tropes, and echoes some 
of the indefinable nuances of Faiz's verse, but unlike Faiz, she is not sending out a call for social change. Faiz's political agenda radically changed the classical imagery of the lover and the beloved, the literal and metaphorical desert of their separation, and the hopeful symbol of the morning breeze charging them with new meaning. The nation became the unattainable beloved and Faiz its devotee, the morning breeze was tinged with revolutionary powers of change, while the pain of separation between the beloved nation and its lovesick poet remained as agonized as ever (Narang 199I, IOO-I2). For Faiz, the poets were "the warriors-/the riders of dawn" who wrote first against colonialism and then against the oppressive postcolonial state giving hope to people where there was none (Hasan 1988, 74). Nur's legendary persona borrows the revolutionary traits of Faiz's poetry.

In Desai's narration Nur holds the key to Urdu's revival. However, it is difficult to say whether Desai's guiding muse in this story is Faiz since the Nur we meet-a poet at the end of his career-contrary to the reader's expectations, is very reluctant to part with the old metaphors and lifestyle of an aristocratic lineage and seems to be untouched by a Progressive outlook. He is obsessed with his pigeons, his body is saturated with an excess of rich foods and alcohol, he lives in a dusty faded house with his two wives and entertains extravagantly. His poetic muse sustains itself through the poetry of Byron and Shelley. This link between the melancholic Romantic English poets and nostalgic Urdu poetry is also developed as a motif in Desai's characterization of Raja in Clear Light of Day. In the days leading up to Partition when Raja is struck down with tuberculosis it is said:

His situation was Romantic in the extreme, Bim could see as she sponged his face and helped him ... his heavy, limp body as she lifted it as spent and sapped as a bled fish, and the city of Delhi burning down about them. He hoped, like Byron, to go to the rescue of those in peril. Instead, like Byron, he lay ill, dying." (1980, 60)

Similarly, Nur too is "prepared for suffering" and his bodily ailments are a mirror to the sickened state of Urdu. But unlike Raja, he is not suffering the flames of Partition, his pain is of a different kind. His pain is embodied in his alter ego Deven, trapped by the harsh realities of a mate- 
rial world but, unlike Nur and Faiz, with a poetic spirit destined for failure locked as it is in the "sufferings of the time" (Kiernan I97I, 65). ${ }^{10}$

In taking on the task of a custodian, Deven must sideline his own creative output in favor of the living poetic legend. But in fulfilling his duty as a custodian he has to overcome many obstacles, some of which are foreseen and others which are not. His immediate priority is to establish contact with the poet and obtain his consent for an interview. In getting close to the poet he finds himself embroiled in the minutiae of Nur's domestic life, an involvement which ultimately spirals out of his control. Contrary to his expectations, he finds himself at the mercy of the two wives, who appear to have charge over Nur's life. Having had the upper hand in his own domestic life, Deven is often confounded by the differing power structures of Nur's household and he is unable to cope with the idea of a woman as an equal, less still as an intellectual.

Through a series of coincidences, Deven is asked by Murad to fulfill his task by immortalizing the verse of Nur in an audio recording. Initially, Deven is dismissive of the idea, seeing it as a belittling gesture to the great poet, reducing his poetry to "some song for the cinema, or radio" (I985, 9I). However, Murad criticizes his small-town sensibility and convinces him that the idea of a tape recording of Nur Shahjahanabadi is "brilliant" even though Deven has never bought or used a radio before. Sarcastically, Murad exclaims, "This is the age of electronics, haven't you heard? Or hasn't the news traveled to Mirpore yet?" (ibid., 92). Murad continues to champion the forces of change and modernity in Deven's life and Deven, despite suspecting his sincerity, submits to his friend's oratory, only to reflect nearer the end of the novel, when things go disastrously wrong, whether their friendship too is another meaningless symbol of a lost custom.

In the Urdu department at Lala Ram Lal College Deven finds an unexpected ally who assists him in acquiring college funds to purchase a tape recorder for his assigned project. Deven's poverty as a Hindi lecturer is matched by the diminishing stature of this colleague who is the head of the Urdu department, Abid Siddiqui. Siddiqui is described as "a small man, whose youthful face was prematurely topped with a plume of white

${ }^{10}$ This poem marks an important initial stage in Faiz's career as a poet. It is particularly important because it changes the conception of the traditional beloved and introduces a modern self-consciousness for the lyric poet. For a critical reading of Faiz as a Progressive poet, see Coppola 1975; also Dryland 1993. 
hair as if to signify the doomed nature of his discipline" (ibid, 96). Lala Ram Lal College could afford the luxury of an Urdu section because of a "very large donation from the descendants of the very nawab who had fled Delhi in the aftermath of the I857 mutiny..." (ibid.). Like the dying culture he represents, Siddiqui lives in a deteriorating haveli which reemphasizes the decay of Urdu and the peripheral position of Muslims in the modern Indian environment. Desai's references to Siddiqui's lifestyle disturbingly reproduce the colonial constructions of a morally decrepit Muslim aristocracy collapsing from drink, debauchery and decay. The inevitable death of this self-indulgent aristocratic Muslim culture is symbolized in the destruction of Siddiqui's house when the "decaying" haveli is razed to the ground by developers and is lost in the metaphorical swirling dust that absorbs Mirpore. Siddiqui has knowingly participated in the sale of his house to a Delhi businessman.

"He wants to ... build a block of flats with shops on the ground floor, cinema house at the back, offices on top.... And as I need the moneyyou know my weakness - the offer was too good to refuse...."

(ibid., 198)

From a different angle, this depiction reinforces the idea that Siddiqui's class can no longer be the custodians of Urdu as they have little power to make themselves heard at the national level. The official situation and status of their language literally makes them outsiders in their own home. Deven has the potential to release the sickened language and its people but he too is constantly reminded of his position as an outsider when he is around Nur and his cronies.

Nur says:

"He has come to speak for me.... Through his throat, my words will flow. Listen and tell me if my poetry deserves to live, or if it should give way to- that fodder chewed by peasants, Hindi?" ...

... Nur was inviting him to join the fray, allowing the sublime concept of time to dwindle into the mere politics of language again.... He knew he ought not to have stayed, listening to this kind of talk, he a Hindu and a teacher of Hindi. He had always kept away from the political angle of languages. (ibid., 54-5)

In this instance Desai overtly connects the theme of language with religion and politics. Ultimately what the novel shows us is that a mother- 
tongue speaker of Urdu, Deven is economically disempowered by his first language, which he studied as a boy in Lucknow, taught to him by his father, a teacher, a scholar, and "lover of Urdu poetry." It does not stand him in good stead when, after his father's death, his mother decides to move to Delhi: "I was sent to the nearest school, a Hindi-medium school, sir" says Deven when he first meets Nur Shahjahanabadi. "I took my degree in Hindi, sir and now I am temporary lecturer in Lala Ram Lal College at Mirpore. It is my living, sir. You see I am a married man, a family man" (ibid., 43). For Deven, in post-independence India, his love for Urdu and his job as a Hindi lecturer are at odds with each other and he finds it increasingly difficult to hold onto both. Nur openly attacks him saying:

"Those Congress-wallahs have set up Hindi on top as our ruler. You are its slave. Perhaps a spy even if you don't know it, sent to the universities to destroy whatever remains of Urdu, hunt it out and kill it....

... It seems you have been sent here to torment me, to show me to what depths Urdu has fallen. (ibid., 42-3)

Deven remains on the fringes of Urdu culture because he does not come from an élite background and has chosen to teach the language that offers better employment prospects and economic growth than an Urdu education. The unexpected opportunity of interviewing Nur temporarily frees him from his caged existence but it is a freedom which is fraught with danger.

This sense of danger is illustrated during Deven's first bus journey to Delhi and is crystallized in an ominous premonition in a teashop after his arrival at the Inter-State Bus Terminal on Ring Road. On finishing his cup of tea

he saw a dead fly floating in the dregs of his tea.

The gasp he gave was only partly of horror at the teashop owner's filthiness and the wretched standards of hygiene in his shop. Or even from a fear of typhoid and cholera. It was the revelation that all the omens of the day had come together and met at the bottom of the glass he held between his fingers. In it lay the struck dog, the triumphant crows, the dead fly-death itself, nothing less. Coming together in the separate prisms of the fly's eye, drowned but glittering in the tea, it stared back at him without blinking. (ibid., 29) 
This portent is mediated through an omniscient narrator who foregrounds the theme of dying through the symbolic motifs of the dog, the crows, and the fly. It appears that Deven's journey has ended before it has begun because the language he wishes to save is already dead. Another way of looking at it is through the idea of shock experienced in the alienating city where Deven is unable to resolve the crisis which unfolds. ${ }^{11}$ His heroism is of a more romantic kind and his ideas are unsustainable in a modern environment.

It is of course inevitable that the tape recorder which is purchased by Deven, with Murad's unreliable help, is a secondhand model, and that he does not know how to operate it so he has to rely on Chiku, a young lad technician, to help him make the recordings. The recorder itself is a symbol of modernity and functionalism, therefore it fails to record the voice of tradition or of premodern India. Chiku's ineptitude with this symbol of progress is a metaphor for the continuing inequalities of language and opportunity in India. The failed recordings are symptomatic of the dysfunctionality of Urdu. "It was a fiasco. There was no other word for it. Disbelievingly, Deven had the first tape removed, the second tried and then the third and the fourth" (ibid, I73).

It seems that the book does offer an alternative vision through the poetry of Nur's second wife, but this vision is rejected by Deven because he sees her as a snake, an impostor who has stolen her husband's verse. Again Imtiaz Begum's character is problematic because it wavers between the typecast intellectual yet predatory courtesan/poet who is a chosen companion of the Progressive, premodern Muslim poet as his second wife and the woman who sends her manuscript to Deven for critical perusal. She cannot shed her first skin as a performer and always has to take a secondary role to Nur. The tone she takes with Deven is confrontational:

"The recording is no secret. Whatever your reason for concealing it from me, Nur Sahib could not conceal it from me. Was I considered incapable of understanding the need to record Nur Sahib's voice for posterity? Was Safiya Begum considered wiser and more capable because of

${ }^{11}$ See Walter Benjamin's chapter entitled "On Some Motifs in Baudelaire" in which he gives a critical reading of Baudelaire's Fleurs du Mal discussing at length the changing sensibility of the lyric poet in modernity (1969, I52-90). There are some very interesting intertexts with Desai, particularly with regards to this novel where she interjects prose with poetry and makes overt her lyrical style of writing. 
her greater age and her longer years with him? Dear friend, I beg to put it to you that you have insulted my intelligence by your deception....

... you thought I was a prostitute who dazzled Nur Sahib's eyes with my dance and so inveigled my way out of a house of prostitution into the house of a distinguished poet....

... Kindly remember that unlike Nur Sahib and unlike your respected self, I am a woman and have had no education but what I have found and seized for myself....

... When you rose to your feet and left the mehfil while I was singing my verse, was it not because you feared I might eclipse the verse of Nur Sahib and other male poets whom you revere? Was it not intolerable to you that a woman should match their gifts and even outstrip them? (ibid., 195-6)

Deven's answer to her challenge is to shred her manuscript and reject her plea as a false one. It seems that Urdu cannot sustain the modernity of a female narrative either.

It can be argued that the problem in Desai's story is that there are no variants of Urdu - she does not draw upon an Urdu lineage of the present. ${ }^{12}$ Her vision of Urdu is in stark contrast to the opinion of the renowned Urdu novelist Intizar Husain, who has argued that the cultural tradition of Urdu lies in its shifting regional locations. According to him this language cannot be associated with one region and one culture because it is by nature hybrid and adaptable to new regions (2000). Desai's Urdu is destined to wither away in the stultifying heat of summer unable to sustain the hopeful beginning of spring. ${ }^{13}$

\footnotetext{
${ }^{12}$ I borrow the phrase from the title of Aijaz Ahmad's book Lineages of the Present.

${ }^{13}$ Interestingly, the novel was adapted as a screenplay for a film of the same name nine years later by the Bombay-born director Ismail Merchant, the successful partner of the internationally acclaimed Merchant-Ivory production group. The script was rewritten in Urdu by Shahrukh Husain in collaboration with Anita Desai. There is a crucial shift of power dynamic in the telling of this tale from an English narration about Urdu to a reappropriation of the story of Urdu in Urdu. Merchant's view about Urdu is completely different than Desai's because he does not think that Urdu can die.
} 


\section{Conclusion}

The central characters, Deven, Murad and Nur, are all caught in a nostalgic remembering of Urdu, wishing to restore it to its former glory. Their nostalgia is rooted in the cultural memory of a premodern past that rejects the values of an evolving modern present. Desai's novel is ostensibly a narrative about the death of a language and raises uncomfortable questions about its demise. It interrogates the dominance of a centralized Hindi which is prescribed as the singular voice of modernity and sidelines traditional cultural values in its drive toward material progress. ${ }^{14}$ The novel displays a critical stance toward modernity, but this criticism is marked by ambivalence in its idea of Urdu, encapsulated as a tradition to be remembered rather than continued. Desai's overall novelistic portrayal of Urdu marks an elegiac farewell to a lost tradition. Her symbolism is tinged with the tropes of a communally charged present, unable to break out of the fragmentary Hindu-Hindi and Muslim-Urdu divide despite her staging the debates within the "secular" Indian-English novel. Despite his many journeys, Urdu's custodian Deven is unable to bridge the metaphorical desert which separates the small regional town of Mirpore and the national capital Delhi because, in the words of one of Nur's cronies: "... Urdu is supposed to have died, in 1947" (ibid., 56). The city of Delhi has absorbed another memory.

\section{Works Cited}

Ahmad, A. 1992. Theory: Classes, Nations, Literatures. London and New York: Verso.

1996. Lineages of the Present: Political Essays. New Delhi: Tulika.

Ali, Agha Shahid, ed. 2000. Ravishing Disunities: Real Ghazals in English. Middleton, Conn.: Wesleyan University Press.

Anderson, B. 1991. Imagined Communities: Reflections on the Origin and Spread of Nationalism. Rev. ed. London: Verso.

Benjamin, W. 1969. "On Some Motifs in Baudelaire." In his Illuminations, edited and with an introduction by Hannah Arendt, translated by Harry Zohn. New York: Schocken.

\footnotetext{
${ }^{14}$ See Certeau (1997), where, in chapter 8, he discusses the dominance of a centralized culture which imposes itself as a singularity and expects celebration of "culture in the singular" in the twentieth century.
} 
Bhabha, H.K., ed. 1990. Nation and Narration. London: Routledge.

Bose, S., and A. Jalal. 1998. Modern South Asia: History, Culture, Political Economy. London: Routledge.

Brass, P. 1974. Language, Religion and Politics in North India. Cambridge: Cambridge University Press.

Certeau, M. de. 1997. In Culture in the Plural, edited and with an introduction by Luce Giard; translated and with an afterword by Tom Conley. Minneapolis: University of Minnesota Press.

Coppola, C. 1975. Urdu Poetry: The Progressive Episode. Ph.D. diss., University of Chicago.

Costa, M. 200I. "Interview With Anita Desai." <http://www.umiacs.umd.edu/ users/sawweb/sawnet/books/desai_interview.html>.

Desai, A. 1980. Clear Light of Day. London: Penguin Books. 1985. In Custody. London: Penguin Books.

Dryland, E. 1993. Faiz Ahmad Faiz I9II-1984: Urdu Poet of Social Realism. Lahore: Vanguard Books.

Eagleton, T. 2000. The Idea of Culture. Oxford: Blackwell.

Faiz, Faiz Aḥmad. 1988. Pakistāñ̄ Kalčar aur Qaumī Tashakhkhuṣ kĩ Talāsh (Pakistani Culture and the Search for National Character). Lahore: Ferozsons.

Farouqui, Athar. 1994. "Urdu Education in India: Four Representative States." Economic and Political Weekly (2 April): 782-5.

Gupta, J.D. 1970. Language Conflict and National Development: Group Politics and National Language Policy in India. Berkeley and London: University of California Press.

Hasan, K., ed. 1988. The Unicorn and the Dancing Girl: Poems of Faiz Ahmad Faiz. Translated by Daud Kamal. London: Independent.

Hasan, Z. 1998. Quest for Power: Oppositional Movements and Post-Congress Politics in Uttar Pradesh. Delhi: Oxford University Press.

Husain, I. 2000. "Urdū kā Tehżībī Mizāì" (The Cultural Disposition of Urdu). The Annual of Urdu Studies 15:pt.2: 372-6.

Jaffrelot, C. 1998. "The Sangh Parivar Between Sanskritization and Social Engineering." In The BJP and the Compulsions of Politics in India. Edited by Thomas Blom Hansen \& Christophe Jaffrelot. Delhi: Oxford University Press.

Kiernan, V., ed. and trans. 1971. Poems by Faiz. Lahore: Vanguard Books.

Khilnani, S. 1998. The Idea of India. London: Penguin Books.

King, C. 1994. One Language, Two Scripts: The Hindi Movement in Nineteenth Century North India. Delhi: Oxford University Press.

Latifi, D. 1999. "Urdu in UP." Nation and the World (I6 August): 44-6.

Lee, C. 200o. "'Hit It With a Stick and It Won't Die': Urdu Language and Muslim Identity and Poetry in Varanasi, India." The Annual Of Urdu Studies I5:pt.I: 337-5I. 


\section{Amina Yaqin • I4I}

Lelyveld, D. 1993. "The Fate of Hindustani: Colonial Knowledge and the Project of a National Language." In Orientalism and the Postcolonial Predicament: Perspectives on South Asia. Edited by Carole Breckenridge and Peter van der Veer. Philadelphia: University of Pennsylvania Press.

Narang, G.C. 1991. Urdu Language and Literature: Critical Perspectives. New Delhi: Sterling.

Rai, Amrit. 1991. A House Divided: The Origin and Development of Hindi-Urdu. Delhi: Oxford University Press.

Rajan, R.S. 1992. The Lie of the Land: English Literary Studies in India. New Delhi: Oxford University Press.

Robinson, F. 1993. Separatism Among Indian Muslims: The Politics of the United Provinces' Muslims 1860-1923. Cambridge: Cambridge University Press.

Said, E.W. 1993. Culture and Imperialism. London: Chatto \& Windus.

Shackle C. and R. Snell. 1990, Hindi and Urdu Since I800: A Common Reader. London: University of London, School of Oriental and African Studies.

Viswanathan, G. 1989. Masks of Conquest: Literary Study and British Rule in India. London: Faber \& Faber. 